Case Reports in
Gastroenterology
Case Rep Gastroenterol 2021;15:436-442

DOI: 10.1159/000511749

Published online: April 27, 2021

\title{
A Hepatitis C Virus-Associated Decompensated Cirrhotic Patient Who Showed the Disappearance of Hepatic Encephalopathy, Ascites, and Pleural Effusion by Antiviral Therapy with Sofosbuvir/Velpatasvir
}

\author{
Kazuo Tarao ${ }^{a}$ Akito Nozaki $^{\mathrm{b}}$ Hirokazu Komatsu $^{\mathrm{c}}$ \\ aTarao's Gastroenterological Clinic, Yokohama, Japan; 'Department of Gastroenterology, \\ Gastroenterological Center, Yokohama City University Medical Center, Yokohama, Japan; \\ 'Department of Gastroenterology, Yokohama Municipal Citizen's Hospital, \\ Yokohama, Japan
}

\section{Keywords}

Hepatitis C virus-associated decompensated liver cirrhosis - Sofosbuvir/velpatasvir · Hepatic encephalopathy · Ascites · Direct-acting antivirals

\section{Abstract}

Oral direct-acting antivirals (DAAs) are the main therapy for hepatitis $\mathrm{C}$ virus (HCV)-associated liver disease in Japan. Moreover, many DAAs include an indication for compensated liver cirrhosis. However, patients with decompensated HCV-associated cirrhosis have hitherto not been indicated for therapy with DAAs. Recently, a new DAA, sofosbuvir/velpatasvir (SOF/VEL), was indicated for decompensated HCV-associated cirrhotic patients. Actually, it has been shown to eradicate HCV in many cases. However, it is not clear whether hepatic encephalopathy, ascites, and pleural effusion in patients with decompensated HCV-associated cirrhosis disappear by SOF/VEL treatment. Recently, we encountered a decompensated HCV-associated cirrhosis patient who showed the disappearance of hepatic encephalopathy, ascites, and pleural effusion with marked improvement of serum ammonia level, albumin level, prothrombin

\begin{tabular}{ll}
\hline & Kazuo Tarao \\
& Tarao's Gastroenterological Clinic \\
& 3rd Floor, Taiyo-Building \\
& $2-58-6$, Futamatagawa, Asahi-ku, Yokohama 241-0821 (Japan) \\
duoluoweih7@gmail.com
\end{tabular}




\section{Case Reports in Gastroenterology}

Case Rep Gastroenterol 2021;15:436-442 DOI: $10.1159 / 000511749$

(c) 2021 The Author(s). Published by S. Karger AG, Basel www.karger.com/crg

Tarao et al.: Hepatitis C Virus-Associated Decompensated Cirrhotic Patient with Antiviral Therapy with Sofosbuvir/Velpatasvir

time, and platelet count after the eradication of HCV by the administration of SOF/VEL. Her consciousness was cloudy and it took many hours for the preparation of each meal just before SOF/VEL treatment, but after the disappearance of HCV-RNA by the therapy, her consciousness became clear and she could prepare meals in a short time. This case suggests the possibility of improvement from decompensated HCV-associated liver cirrhosis to compensated liver cirrhosis with disappearance of hepatic encephalopathy, ascites, and pleural effusion by SOF/VEL therapy.

\section{Introduction}

Antiviral therapy using oral direct-acting antivirals (DAAs) has recently become the main and most effective therapy for eradicating hepatitis C virus (HCV) in Japan [1-10]. Moreover, many DAAs have been proposed to eradicate $\mathrm{HCV}$ in patients with compensated HCV-associated liver cirrhosis [1-10]. However, patients with decompensated HCV-associated cirrhosis have hitherto not been indicated for therapy with DAAs. Furthermore, they were in a lifethreatening state and eradication of $\mathrm{HCV}$ was not possible.

Now, a new DAA, sofosbuvir/velpatasvir (SOF/VEL), is indicated for eradicating HCV in patients with decompensated $\mathrm{HCV}$-associated liver cirrhosis $[11,12]$. We recently encountered an HCV-associated decompensated cirrhotic patient whose hepatic encephalopathy, ascites, and pleural effusion disappeared after HCV-RNA became negative due to the administration of SOF/VEL with marked improvement of the serum ammonia level, serum albumin level, prothrombin time, and platelet count.

\section{Case Report}

A 54-year-old Japanese female (height $156.0 \mathrm{~cm}$; weight $73.0 \mathrm{~kg}$ ) with HCV-associated cirrhosis (genotype Ib) visited our clinic for the treatment of cirrhosis. She was treated with the oral administration of ursodeoxycholic acid at $600 \mathrm{mg} /$ day. From May 31, 2011, injection of $80 \mathrm{~mL}$ of Stronger Neo-Minophagen C (usually used to lower serum transaminase, 2-3 times a week) was carried out until the end of August 2019.

Abdominal computed tomography (CT) was carried out on February 10, 2011, which showed unevenness of the surface of the liver with splenomegaly, and she was diagnosed with a cirrhotic state. For eradication of HCV, PEG-IFN/ribavirin therapy was performed from August 5 to December 5, 2012, but it was not effective. Thereafter, CT performed on February 6 , 2018, showed ascites and pleural effusion (Fig. 1a, b) and she was diagnosed with decompensated liver cirrhosis. Furosemide and Aldactone A were administered, but pleural effusion and ascites remained. For the low albumin level, albumin infusion was carried out from March 22, 2016, to August 30, 2019 (every 2 weeks).

On August 3, 2019, a new DAA drug, SOF (NS5B inhibitor, $400 \mathrm{mg}$ )/VEL (NS5A inhibitor, $100 \mathrm{mg}$ ), was administered until October 25, 2019 (about 12 weeks). HCV-RNA became negative on August 30, 2019. Abdominal CT performed on September 25 showed neither ascites nor pleural effusion (Fig. 2a, b).

Hepatic encephalopathy (grade I-II), which appeared on July 23, 2019 (the patient claimed cloudiness of sensation, serum ammonia level of $112 \mu \mathrm{g} / \mathrm{dL}$ ), disappeared on October

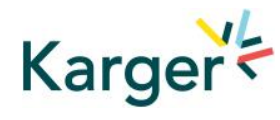




\section{Case Reports in Gastroenterology}

Case Rep Gastroenterol 2021;15:436-442

\begin{tabular}{l|l|l}
\hline DOI: 10.1159/000511749 & $\odot 2021$ The Author(s). Published by S. Karger AG, Basel \\
\hline
\end{tabular} www.karger.com/crg

Tarao et al.: Hepatitis C Virus-Associated Decompensated Cirrhotic Patient with Antiviral Therapy with Sofosbuvir/Velpatasvir

7, 2019 (serum ammonia level of $85 \mu \mathrm{g} / \mathrm{dL}$ ) (Fig. 3). She stated that her consciousness was cloudy and it took many hours for the preparation of each meal just before the SOF/VEL treatment, but after the disappearance of HCV-RNA by the therapy, her consciousness became clear and she could prepare a meal in a short time. Furthermore, she also stated that the sensation of fatigue had disappeared, and it had become easier to move by the 6th week of administration of the drugs. In addition, she also showed marked improvements in the albumin level (Fig. 4) and in prothrombin time (Fig. 5). As a result, the Child-Pugh classification [13,14] improved from Child B to Child A.

\section{Discussion}

There are many DAA agents to eradicate HCV which include the indication for compensated cirrhosis [1-10]. However, hitherto, there has been no DAA agent which includes decompensated liver cirrhosis as an indication.

Recently, SOF/VEL was firstly indicated for decompensated liver cirrhosis. It was confirmed that this agent improves the serum albumin level, prothrombin time, and sometimes the serum ammonia level [12] after eradication of HCV. However, it has not been confirmed whether hepatic encephalopathy, ascites, and pleural effusion disappear clinically after the eradication of HCV by SOF/VEL administration. Our case showed that hepatic encephalopathy, ascites, and pleural effusion in decompensated cirrhosis may disappear completely by the administration of SOF/VEL. In support of our findings, Younossi et al. [11] analyzed patient-reported outcomes from decompensated cirrhotic patients treated by SOF/VEL and found that SOF/VEL therapy led to a significant improvement in patient-reported outcomes by 4 weeks of administration.

In addition, our case showed marked improvements in the serum ammonia level $(112 \rightarrow 75 \mu \mathrm{g} / \mathrm{dL})$, albumin level $(3.3 \rightarrow 4.1 \mathrm{~g} / \mathrm{dL})$, and prothrombin time $(70.9 \rightarrow 85.8 \%)$, respectively. With regard to these findings, Takaoka et al. [12] administered SOF/VEL for 12 weeks to 43 patients with decompensated cirrhosis, and they reported that the serum albumin level improved to $3.2 \mathrm{~g} / \mathrm{dL}$ on average, and prothrombin time improved to $70 \%$ on average. Considering their results, our case demonstrated marked improvements in the serum albumin level and prothrombin time.

In summary, this case suggests the possibility of improvement from decompensated HCVassociated liver cirrhosis to compensated liver cirrhosis with disappearance of hepatic encephalopathy, ascites, and pleural effusion by SOF/VEL therapy. This drug may become an effective treatment option for decompensated HCV-associated cirrhotic patients with ascites, pleural effusion, or hepatic encephalopathy.

\section{Statement of Ethics}

The authors have no ethical conflicts to disclose. Informed consent was obtained from the patient to be included in this report. And the patient has given written informed consent to publish her case (including publication of images). This study was conducted in accordance with the Declaration of Helsinki and was approved by the Medical Ethics Committee on $\mathrm{Hu}-$ man Research of Yokohama Municipal Citizen's Hospital.

\section{Karger'"}




\section{Case Reports in Gastroenterology}

\begin{tabular}{l|l}
\hline DOI: 10.1159/000511749 & @ 2021 The Author(s). Published by S. Karger AG, Basel
\end{tabular} www.karger.com/crg

Tarao et al.: Hepatitis C Virus-Associated Decompensated Cirrhotic Patient with Antiviral Therapy with Sofosbuvir/Velpatasvir

\section{Conflict of Interest Statement}

The authors declare that they have no conflicts of interest.

\section{Funding Sources}

This work was supported by the Kanagawa Association of Medical and Dental Practitioners.

\section{Author Contributions}

Kazuo Tarao: follow-up of the patient's clinical course. Akito Nozaki: summary of the paper. Hirokazu Komatsu: performing clinical examinations including gastrointestinal endoscopy.

\section{References}

1 Chayama K, Takahashi S, Toyota J, Karino Y, Ikeda K, Ishikawa H, et al. Dual therapy with the nonstructural protein $5 \mathrm{~A}$ inhibitor, daclatasvir, and the nonstructural protein 3 protease inhibitor, asunaprevir, in hepatitis C virus genotype 1b-infected null responders. Hepatology. 2012 Mar;55(3):742-8.

2 Kumada H, Suzuki Y, Ikeda K, Toyota J, Karino Y, Chayama K, et al. Daclatasvir plus asunaprevir for chronic HCV genotype 1b infection. Hepatology. 2014 Jun;59(6):2083-91.

3 Afdhal N, Zeuzem S, Kwo P, Chojkier M, Gitlin N, Puoti M, et al.; ION-1 Investigators. Ledipasvir and sofosbuvir for untreated HCV genotype 1 infection. N Engl J Med. 2014 May;370(20):1889-98.

4 Mizokami M, Yokosuka O, Takehara T, Sakamoto N, Korenaga M, Mochizuki H, et al. Ledipasvir and sofosbuvir fixed-dose combination with and without ribavirin for 12 weeks in treatment-naive and previously treated Japanese patients with genotype 1 hepatitis C: an open-label, randomised, phase 3 trial. Lancet Infect Dis. 2015 Jun;15(6):645-53.

5 Chayama K, Notsumata K, Kurosaki M, Sato K, Rodrigues L Jr, Setze C, et al. Randomized trial of interferonand ribavirin-free ombitasvir/paritaprevir/ritonavir in treatment-experienced hepatitis C virus-infected patients. Hepatology. 2015 May;61(5):1523-32.

6 Kumada H, Chayama K, Rodrigues L Jr, Suzuki F, Ikeda K, Toyoda H, et al. Randomized phase 3 trial of ombitasvir/paritaprevir/ritonavir for hepatitis $\mathrm{C}$ virus genotype $1 \mathrm{~b}$-infected Japanese patients with or without cirrhosis. Hepatology. 2015 Oct;62(4):1037-46.

7 Kwo P, Gane EJ, Peng CY, Pearlman B, Vierling JM, Serfaty L, et al. Effectiveness of elbasvir and grazoprevir combination, with or without ribavirin, for treatment-experienced patients with chronic hepatitis $\mathrm{C}$ infection. Gastroenterology. 2017 Jan;152(1):164-175.e4.

8 Kumada H, Suzuki Y, Karino Y, Chayama K, Kawada N, Okanoue T, et al. The combination of elbasvir and grazoprevir for the treatment of chronic HCV infection in Japanese patients: a randomized phase II/III study. J Gastroenterol. 2017 Apr;52(4):520-33.

9 Gane E, Poordad F, Wang S, Asatryan A, Kwo PY, Lalezari J, et al. High efficacy of ABT-493 and ABT-530 treatment in patients with HCV Genotype 1 or 3 infection and compensated cirrhosis. Gastroenterology. 2016 Oct;151(4):651-659.e1.

10 Chayama K, Suzuki F, Karino Y, Kawakami Y, Sato K, Atarashi T, et al. Efficacy and safety of glecaprevir/pibrentasvir in Japanese patients with chronic genotype 1 hepatitis $\mathrm{C}$ virus infection with and without cirrhosis. J Gastroenterol. 2018 Apr;53(4):557-65.

11 Younossi ZM, Stepanova M, Charlton M, Curry MP, O'Leary JG, Brown RS, et al. Patient-reported outcomes with sofosbuvir and velpatasvir with or without ribavirin for hepatitis $C$ virus-related decompensated cirrhosis: an exploratory analysis from the randomised, open-label ASTRAL-4 phase 3 trial. Lancet Gastroenterol Hepatol. 2016 Oct;1(2):122-32. 


\section{Case Reports in Gastroenterology}

\begin{tabular}{l|l}
\hline Case Rep Gastroenterol 2021;15:436-442 \\
\hline DOI: 10.1159/000511749 & $\begin{array}{l}\text { ○ 2021 The Author(s). Published by S. Karger AG, Basel } \\
\text { www.karger.com/crg }\end{array}$ \\
\hline
\end{tabular}

Tarao et al.: Hepatitis C Virus-Associated Decompensated Cirrhotic Patient with Antiviral Therapy with Sofosbuvir/Velpatasvir

12 Takaoka Y, Miura K, Morimoto M, Kakizaki S, Ikegami T, Ueno T, et al. Efficacy and safety of 12-week sofosbuvir/velpatasvir treatment of patients with decompensated liver cirrhosis caused by hepatitis $\mathrm{C}$ virus infection [in Japanese]. Kanzo. 2020;61(5):276-8.

13 Child CG. The Liver and Portal Hypertension. MPCS. Philadelphia: Saunders; 1964. p. 50.

14 Pugh RN, Murray-Lyon IM, Dawson JL, Pietroni MC, Williams R. Transection of the oesophagus for bleeding oesophageal varices. Br J Surg. 1973 Aug;60(8):646-9.
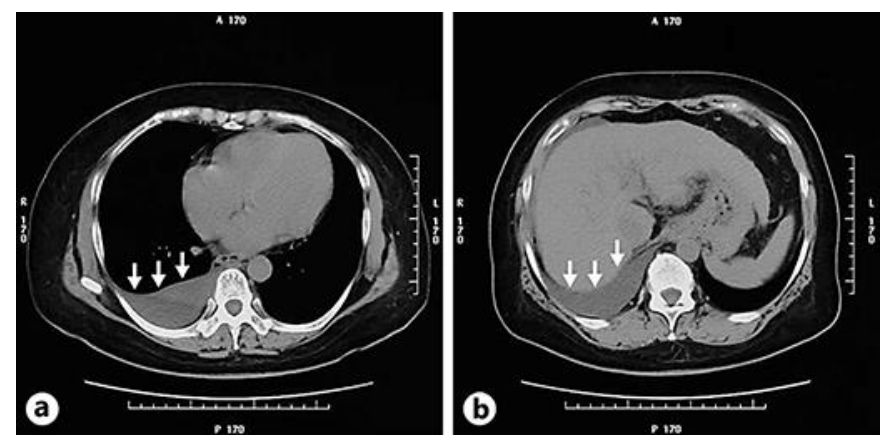

Fig. 1. a Chest CT on February 6, 2018 (before the administration of SOF/VEL), showed pleural effusion in the lower part of the right lung. The white arrows show pleural effusion. b Abdominal CT on February 6, 2018 (before the administration of SOF/VEL), showed ascites in the lower part of the liver. The white arrows show ascites.
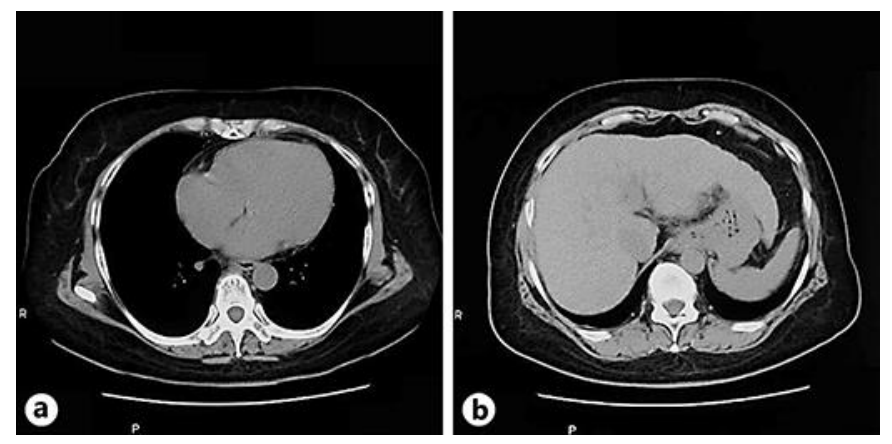

Fig. 2. a Chest CT on September 25, 2019 (after the administration of SOF/VEL), showed that the pleural effusion in the lower part of the right lung had disappeared completely. b Abdominal CT on September 25, 2019 (after the administration of SOF/VEL), showed that the ascites in the lower part of the liver had disappeared completely.

\section{Karger'}


Case Reports in Gastroenterology
Case Rep Gastroenterol 2021;15:436-442

DOI: $10.1159 / 000511749$

(c) 2021 The Author(s). Published by S. Karger AG, Basel www.karger.com/crg

Tarao et al.: Hepatitis C Virus-Associated Decompensated Cirrhotic Patient with Antiviral Therapy with Sofosbuvir/Velpatasvir

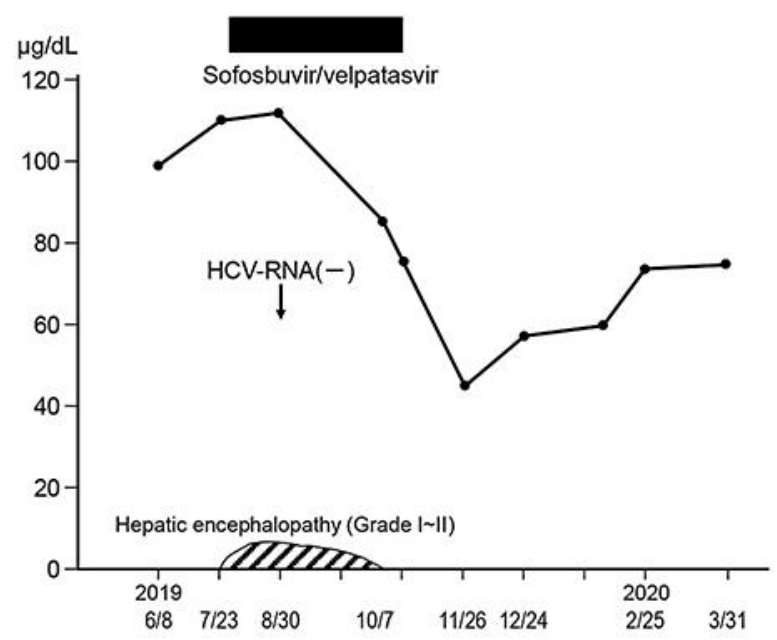

Fig. 3. Time course of serum ammonia level after SOF/VEL administration.

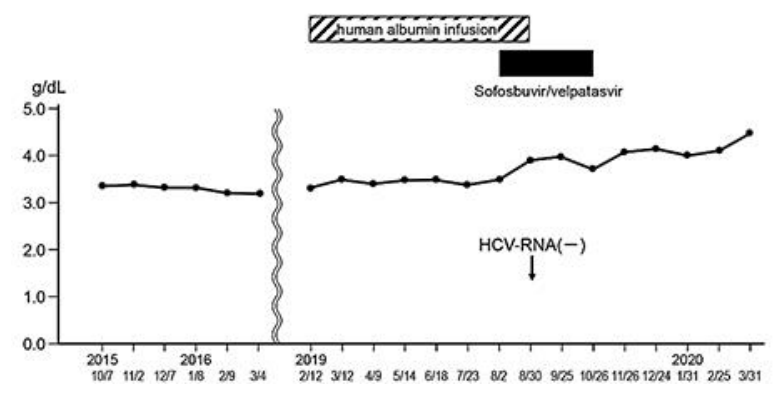

Fig. 4. Time course of serum albumin level after SOF/VEL administration. 
Case Reports in Gastroenterology
Case Rep Gastroenterol 2021;15:436-442

DOI: $10.1159 / 000511749$

(c) 2021 The Author(s). Published by S. Karger AG, Basel www.karger.com/crg

Tarao et al.: Hepatitis C Virus-Associated Decompensated Cirrhotic Patient with Antiviral Therapy with Sofosbuvir/Velpatasvir

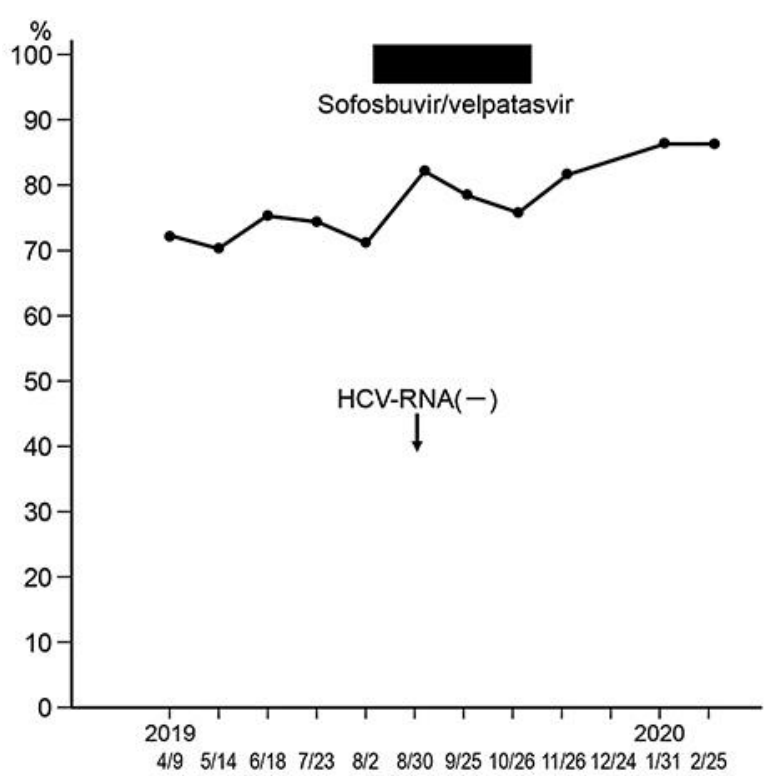

Fig. 5. Time course of prothrombin time after SOF/VEL administration. 